William R. Penuel, Erin Marie Furtak \& Caitlin C. Farrell

\title{
Research-Practice Partnerships in Education: Advancing an Evolutionary Logic of Systems Improvement
}

\begin{abstract}
Over the past several decades, scholars have proposed a number of innovative approaches to bridging the research-practice divide. A relatively new approach involves the formation of research-practice partnerships (RPPs), long-term collaborations aimed at educational improvement and transformation through engagement with research, intentionally organized to connect diverse forms of expertise and to ensure that all partners have a say in the joint work. This paper develops the idea that RPPs have the potential to create sustainable change, if they are able to support the mutual learning of partners to change practice while continuously adapting to turbulent environments of schools. As an illustration, the paper describes the evolution of an RPP in Colorado (U.S.A.) from a relatively small group of people representing a university and school district focused on a single line of research to an ongoing enterprise linking multiple researchers and educators to multiple lines of work to transform science teaching and learning in the district. Keywords: research-practice partnerships, institutional logics, evolution, learning, educational change
\end{abstract}

\section{Wissenschaft-Praxis-Partnerschaften im Bildungsbereich:}

Die Förderung einer evolutionären Logik zur Systemverbesserung

\section{Zusammenfassung}

In den vergangenen Jahrzehnten haben Forscher*innen zahlreiche innovative Vorschläge gemacht, wie die Kluft zwischen Wissenschaft und Praxis am besten zu überbrücken sei. Ein relativ neuer Ansatz zielt auf die Bildung von Wissenschaft-Praxis-Partnerschaften (RPPs), d.h. auf eine langfristige Zusammenarbeit, die unter Verwendung von Forschungsergebnissen zur Verbesserung und Veränderung des Bildungssystems beitragen soll; solche Partnerschaften werden ganz bewusst eingegangen, um unterschiedliche Formen von Expertise zusammenzubringen und sicherzustellen, dass alle Beteiligten ein Mitspracherecht haben. In diesem Beitrag wird die Vorstellung erläutert, dass RPPs 
das Potenzial besitzen, zu nachhaltigen Veränderungen beizutragen, wenn es ihnen gelingt, das wechselseitige Voneinander-Lernen zu unterstützen und die Schulpraxis permanent den turbulenten Rahmenbedingungen anzupassen. Zur Veranschaulichung wird die Entwicklung eines RPP in Colorado (U.S.A.) beschrieben: von einer relativ kleinen Gruppe von Vertreter ${ }^{\star}$ innen der Universität und des Schulbezirks, die sich einer bestimmten Forschungsfrage widmete, zu einer gut funktionierenden „Unternehmung“, die verschiedenste Forscher ${ }^{\star}$ innen und Pädagog ${ }^{\star}$ innen bei der Bearbeitung zahlreicher Anliegen zusammenbringt, um den Unterricht in den naturwissenschaftlichen Fächern im Schulbezirk zu verbessern.

Schlüsselwörter: Wissenschaft-Praxis-Partnerschaften, institutionelle Logik, Evolution, Lernen, Bildungssystemwandel

\section{Introduction}

Policy makers, funders, researchers, and educators across the globe have become increasingly concerned about the impact of research on instructional practice. Many of these concerns have been raised for decades (Lagemann, 2002) and across national borders (e.g., Koninklijke Nederlandse Akademie van Wetenschappen, 2018). Approaches to bridge the research-practice divide have been promoted, and many have enjoyed some popularity among scholars, educators, and policymakers alike for a time. Approaches such as action research or Aktionsforschung, practice research or Praxisforschung, and accompanying research or Begleitforschung have broadened the aperture of who participates in research and have allowed for the development of local knowledge to improve educational outcomes.

In this conceptual paper, we develop the idea of research-practice partnerships (RPP) in educational research as enterprises that seek to engage in mutual learning in order to improve or transform practice, while continuously adapting to changing environments in an effort to persist as a force for change within educational systems. We characterize RPPs as adhering to a different institutional logic for school improvement than is dominant within education in the U.S. and elsewhere, one that adheres to principles of organizational evolution (Aldrich, 1999; Hannan \& Freeman, 1989) rather than following a logic of efficiency. We illustrate this idea by presenting an example of the evolution of one long-term partnership between a local school district and research university in Colorado (U.S.). Finally, we conclude with a discussion of the vulnerabilities of RPPs to internal dynamics as well as to changes in their external environments and the kinds of infrastructures needed to ensure they are not just another short-lived effort to bridge the research-practice divide. 


\section{Theoretical and Conceptual Background}

We write from the policy context of the United States, where a network of requirements and resources have supported both the generation and use of evidence of program effectiveness. The policies provide resources for an infrastructure of research and development that adheres to a structured sequence of basic research, development, evaluation, and dissemination of innovations that is drawn from medical research (Peurach \& Glazer, 2012). There is an emphasis on developing credible evidence from experimental studies that decision makers can use to select effective innovations to address persistent problems of practice. The expectation is that widely available experimental evidence of program effectiveness, coupled with strong inducements for practitioners to use evidence, will allow evidence to replace politics in local decision making (Haskins \& Baron, 2011).

There are a number of problems with this model for research, despite its logical appeal. For one, this set of policy inducements does not reflect what we know about the conditions that support evidence use in practice. It is far too easy for governing bodies in local education agencies to make cursory references to what research says rather than engage substantively with complex study findings (Asen, Gurke, Solomon, Conners \& Gumm, 2011), and interest groups and intermediary organizations can and do "spin" research findings to fit their ideological agendas (Scott, Lubienski, DeBray \& Jabbar, 2014). Further, even under the best of conditions, research is likely to be only one source of information guiding decision making, which unfolds over multiple settings and involves many different actors (Huguet, Allen, Coburn \& Farrell, in press). Syntheses of evidence use suggest that institutionalized structures of communication that involve regular, bi-directional conversations between researchers and practitioners are necessary (Contandriopoulos, Lemire, Denis \& Tremblay, 2010). Knowledge transfer benefits from such an approach, because of the need to leverage the expertise for improvement from different sectors, including research, policy, and practice (Bremm \& Manitius, 2019).

\section{The Need for a New Logic of Improvement}

The developments of the past two decades reflect significant changes to patterns of control in U.S. educational systems. Inspired by a critique of schools as underperforming and therefore putting the nation at economic risk, a new policy paradigm emerged in which education reform became a more dominant feature of the political landscape, and accountability became a primary mechanism for improvement (Mehta, 2013), much as the "PISA-Schock" did in Germany. New policies adopted at the federal level sought to tighten the loose coupling that existed between policy and practice in the U.S. education system, by holding schools and districts to account for 
student outcomes (Spillane \& Burch, 2006). The effort to promote the use of evidence is just one example of an effort to tighten the coupling between federal policy and local practice to support accountability goals.

Despite these particular efforts to link policy, research, and practice, an underlying logic of efficiency (Callahan, 1962) persists in ways that position researchers in a way that is purposefully distal to practice, and therefore unable to easily engage with local decision makers and educators in a way that research suggests is necessary for meaningful evidence use to occur. This logic of efficiency is a legacy of the introduction of Taylorism to education, in which educational researchers were expected to provide the science to support the scientific management of schools (Lagemann, 1997). This would seem to necessitate collaborations with school leaders, but education researchers were enjoined not to waste time engaging with practitioners (cp. Jonçich, 1968, pp. 230-231). In today's policies encouraging research use, this logic persists: research is expected to provide independent evidence that helps education leaders make decisions based on the relative cost-effectiveness of alternative interventions (Dynarski, 2006), and there remain strong incentives to education researchers in the field to focus their time on the production of research rather than on developing collaborations with practitioners, even in institutions with a commitment to engaged practicescholarship (Fischman, Anderson, Tefera \& Zuiker, 2018).

An alternative to a logic of efficiency, in which improvement depends on intelligent management and independent researchers allied solely with administrative goals, is an institutional logic of evolution. Drawing on organizational theory (Aldrich, 1999; Hannan \& Freeman, 1989), we define evolution as the progressive development of an enterprise over time from a simpler, more vulnerable form as it exercises agency in reconciling internal aims with external environments (Peurach, Penuel \& Russell, 2019). Here, an enterprise refers to a specific effort to improve or transform learning within schools or systems of schools in a local education agency, a system that has its own aims but also exists within a changing, often turbulent environment to which it must continually adapt. Any enterprise starts out vulnerable, because the environment is likely to put competing demands on its actors' time, and may operate according to competing institutional logics, such as that of efficiency. It becomes more viable, to the extent that it develops stronger relationships among its actors, creates more "crystallized" (Akkerman \& Bakker, 2011) or institutionalized practices for joint work, and becomes established as a legitimate actor within a particular environment.

A logic of evolution puts an imperative on collective learning within an enterprise. That imperative arises from the fact that we as researchers, education leaders, and practitioners face persistent problems and puzzles of practice, both in terms of how to organize teaching and learning and in terms of how to organize ourselves as a field for improving it (Bryk, Gomez, Grunow \& LeMahieu, 2015). It grows out of the observation that there are few, if any, ready-made solutions for systems change, except 
in specific niches where they can be protected from threats in the wider environment (Cohen \& Mehta, 2017). It also assumes that technical solutions alone are inadequate to address the persistent inequalities and systemic injustices that reproduce failure in schools (Oakes \& Rogers, 2007). Finally, this logic presumes that networks and collaboratives working together over sustained periods of time developing and testing solutions to these problems are required, not only because researchers do not possess sufficient knowledge to solve these problems, but also because supporting the agency of stakeholders is a value in its own right within democratic institutions like schools (Penuel, Riedy, Barber, Peurach, LeBoeuf \& Clark, 2020).

An enterprise's adaptability depends on engaging in and coordinating two forms of learning simultaneously, exploration and exploitation (Peurach \& Glazer, 2012). Exploration in a network often involves a small group that comes together and encompasses related lines of activity focused on examining local needs, searching for new ideas and strategies to address needs, and inventing, testing, and iteratively refining hybrid solutions to problems. Exploitation involves capturing the knowledge gained through exploration within routines, tools, guidelines, and other resources and supporting their use in classroom through various means, including professional development and coaching. A mature enterprise that is operating within an evolutionary logic is often engaged in multiple lines of exploration and exploitation and is also engaged in coordinating those lines of activity in an effort to promote coherent, rather than piecemeal change to systems.

\section{Research-practice Partnerships as Enterprises Following an Evolutionary Logic}

Research-practice partnerships are a type of enterprise that adheres to an evolutionary logic. A research-practice partnership (RPP) is a long-term collaboration aimed at educational improvement and transformation through engagement with research, intentionally organized to connect diverse forms of expertise and to ensure that all partners have a say in the joint work (Farrell, Penuel, Coburn, Daniel \& Steup, 2020). It is neither an action research project targeted to individual teachers' professional growth, nor is it simply a more effective instrument for carrying out translational research. Rather, an RPP involves a network of educators engaged in collective learning with research partners through continuous engagement in joint work at the boundaries of research and practice (Penuel, Allen, Farrell \& Coburn, 2015).

We describe RPPs as adhering to an evolutionary logic for several reasons. For one, they typically start out with a single line of work within a complex environment, an enterprise that is highly vulnerable to changes in personnel and policy (Farrell et al., 2018). What enables a fledgling RPP to survive are different kinds of early successes: 
coming to terms with what kinds of problem of practice can be addressed by the people at the table (Furtak, Henson \& Buell, 2016; Penuel, Coburn \& Gallagher, 2013), coordinating timelines and establishing clear roles for researchers and practitioners (Farrell, Harrison \& Coburn, 2019), and successfully carrying out an early test of an innovation (Donovan, Snow \& Daro, 2013). As RPPs continue to "follow the contours of the problems" (Donovan, 2013) they are seeking to solve, their work often expands and evolves to include new people who bring in relevant expertise needed, the establishment of routines for joint work, and the development of strategies for adapting to changes in RPPs' multiple environments (Davidson \& Penuel, 2019; Farrell et al., 2019; Russell, Bryk, Dolle, Gomez, LeMahieu \& Grunow, 2017). In a number of cases, this has led to long-term partnerships of ten or more years duration with multiple lines of work, where exploration and exploitation activities are coordinated simultaneously, both within and across educational systems (e.g., Snow \& Donovan, 2018; Penuel, 2019; Roderick, Easton \& Sebring, 2009).

In an RPP, the organization of these activities serves a larger goal of promoting collective learning, another key attribute of an enterprise operating within an evolutionary logic. A key goal of an RPP is to bring together the diversity of backgrounds, experience, and know-how that is needed to make progress on the goals of the partnership (Farrell, Penuel, Allen, Anderson, Bohannon, Coburn \& Brown, 2020). Neither schools nor research teams are typically organized for purposes that require eliciting and making use of the kinds of expertise that the typical RPP brings, but rather for each partner to "do its part" in either planning and carrying out research activities or implementing an innovation, creating possibilities for role confusion (Coburn \& Penuel, 2016). However, in a successful RPP organized for mutual learning, individuals and organizations develop new capacities for engaging in exploration and exploitation to solve problems, as well as new ways of engaging in joint work in ways that blur the roles of researcher and practitioner (Henrick, Cobb, Penuel, Jackson \& Clark, 2017).

The involvement of partners in different aspects of research speaks to another key element in what defines an RPP: ensuring all participants have a say in the joint work. This reverses traditional paradigms where researchers are in positions of power to define questions and interpretations of findings. Instead, a hallmark of RPP work is that partners give careful attention to who defines and tells the story of the work together. No matter the level of involvement of partners in the research, RPPs identify concerns or issues to be addressed through a process that seeks perspectives of multiple participants and stakeholder groups, and participants have opportunities to weigh in on, or participate in, different aspects of the joint work over the course of the partnership. 
We acknowledge the similarities between RPPs and other approaches to educational research that center the expertise of practitioners. Several approaches to Aktionsforschung (action research), first popularized in the 1980s and 1990s, provide a means for teachers to investigate their own practice and to use their inquiries as a means to improve it (Altrichter \& Posch, 2007). Praxisforschung (practice research) has sought to challenge the institutionalized dynamic between research and practice through research carried out in the workplace by teachers in ways that are institutionally supported and often accompanied by research (Altrichter \& Feindt, 2004). Third, the institutionalized practice of Begleitforschung (accompanying research) linked to various pilot projects provides educators with structured ways to participate in co-design activities with researchers engaged in studies of innovative programs (e.g., Kämäräinen, 2017).

Like action and practice research, RPPs value the practical knowledge of educators and engage them as co-participants in research activities. At the same time, scholars engaged in research-practice partnerships aim to produce generalizable knowledge (Henrick et al., 2017) and study dynamics and outcomes both empirically and critically, using a variety of approaches, including conducting experiments (Blazar \& Kraft, 2019), case studies (e.g., Denner, Bean, Campe, Martinez \& Torres, 2019), and design studies (e.g., Borko et al., 2017). This stands in contrast to much action research, practice research, and accompanying research, which focuses on the development of locally relevant knowledge and evidence of the impact of innovations.

Another important way that RPPs are different from other models for closing the research-practice divide and from traditional research models is that they are focused on supporting and studying the institutionalization of educational change. In some cases, accomplishing systems change may require innovation, that is, the development and testing of new designs for learning (e.g., Booth, Cooper, Donovan, Huyghe, Koedinger \& Pare-Blagoev, 2015). But in other cases, existing designs may be available that can be adapted and institutionalized across an educational system such as a school district (Penuel et al., 2017) or state (Russell et al., 2020). What determines the course and evolution of research is not a prescribed sequence that moves ideas and strategies from research to practice or the desires of either researchers or educators. Instead, in an RPP teams engage in mutual learning (evolution) by continuously negotiating and re-negotiating the focus of their joint work, following the contours of problems as they evolve and as environments change (Donovan, 2013). As they do, they may strengthen and evolve multiple lines of work, though they remain vulnerable to changes from within (e.g., turnover) and from without (e.g., changing policy environments) (Farrell et al., 2018). 


\section{An Illustration of How One RPP Approached the Imperatives to Learn and Adapt}

Erin Furtak, one of the authors of this paper, has conducted multiple studies over the past 15 years which explore the ways in which science teachers design formative assessment tasks as part of long-term professional learning experiences that support both teacher and student learning. Several studies (e.g., Furtak, 2012; Furtak, Circi \& Heredia, 2018; Furtak, Thompson, Braaten \& Windschitl, 2012) have sought to better understand the ways in which learning progressions, or representations of the development of student ideas in a domain of science, might support teachers in designing and enacting formative assessment tasks in high school science teaching. She began her career within a project that shared many characteristics of action and practice research (Furtak et al., 2008), conducted in collaboration with teachers as they inquired into their own practice. These studies also led her to consider how she might engage in a longer-term partnership with a district that could support more lasting change not just for individuals but also within systems.

\subsection{Following the Logic of Efficiency: Individual Studies}

Early studies in Furtak's research agenda featured university-based researchers recruiting groups of individual teachers working at high schools to participate in a study with a clearly defined beginning and endpoint. While district personnel approved the research protocols, and leaders at each school were familiar with the study and provided permission to contact teachers, the research was conducted almost exclusively with teachers at the schools over the course of multiple academic years. Researchers designed the interventions and then studied their influence on teachers' classroom practices and student learning as measured by pre-post assessments administered early and late in each academic year. When the original study design was completed, the working relationship ended: the researcher returned to the university to analyze data, and the teachers continued in their individual careers. These studies were built upon the logic of efficiency model - where a project is conducted, and when it's finished, the empirical results are derived by the researcher and then disseminated to researcher and practitioner communities. While seeing changes in practice and student learning was satisfying to the researcher (Furtak et al., 2018), it was challenging to discover that, after the structure of the research project was taken away, teachers no longer had the space or opportunity to engage in these sustained inquiries into their own teaching practice. 


\subsection{Following the Logic of Evolution: the Aspire Partnership}

Following the studies described above which were predicated on a logic of efficiency, Furtak was approached by science curriculum coordinators in a different local school district in 2014 who were interested in supporting their science teachers in formative assessment linked to the new science standards (NGSS Lead States, 2013). After meeting with the curriculum coordinators, Furtak immediately noticed overlapping interests between both the researcher's areas of expertise and the district's interest and needs in supporting the professional learning of their teachers. They identified a set of goals to assess the current needs of science teachers and to develop a framework organizational structure to collaboratively design professional learning for these teachers and wrote a proposal to the U.S. National Science Foundation (NSF) to support this funding. However, unlike the previous examples, this project requested funding to develop infrastructure for the partnership through the formation and study of a multi-leveled leadership structure for the partnership. This multi-leveled leadership represented a significant departure from prior work, where Furtak worked primarily with teacher teams, without the mediation or significant involvement of school and district leaders.

Over the course of many years, this partnership - which came to be called Aspire has been sustained through a series of federal, private, and university-based grants, as shown in Figure 1, and has expanded from supporting secondary science teachers to support science instruction across the K-12 spectrum.

Fig. 1: Growth of multiple projects within the Aspire partnership

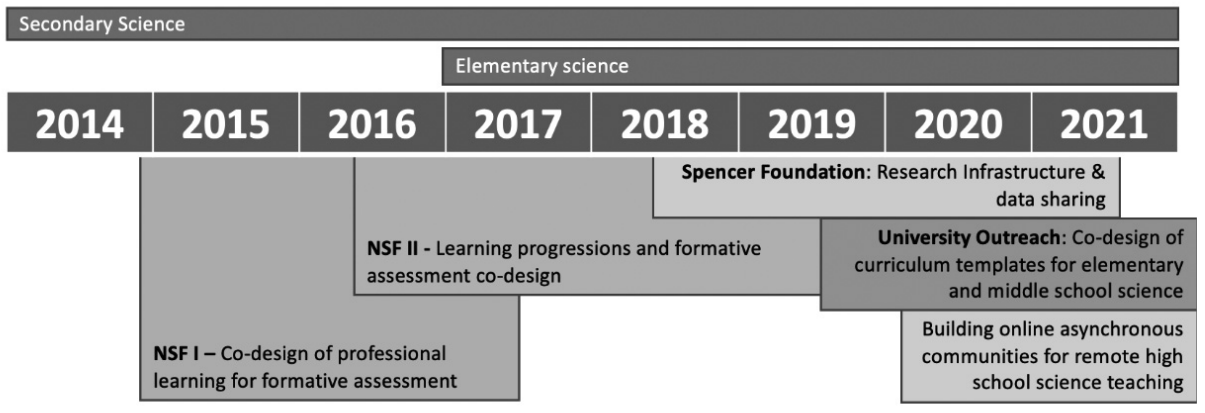

Source: own research

As Figure 1 illustrates, the initial partnership was funded by a grant from the National Science Foundation in 2014 that involved building a team of university researchers and district science coordinators to co-design districtwide professional learning for formative assessment linked to the new standards, a project focused si- 
multaneously on innovation (design of new professional development) and institutionalization (offering and testing the professional development districtwide). Over time, the partnership sought and received more funding for additional projects, including a quasi-experimental study, as well as a research infrastructure grant from the Spencer Foundation that created a full-time teacher on special assignment role to support the professional learning of secondary science teachers and to ease processes for sharing student assessment data between the district and university. Later projects have involved designing templates and tools for elementary and middle school science curriculum, as well as continuing to build communities of practice for science teachers during the COVID-19 pandemic of 2020.

Taken together, the growth of the partnership from a single project with a single funder to multiple, overlapping projects that engage in innovation and institutionalization activities simultaneously illustrate what is distinctive about the RPP approach to research and development. Because of the pressure to provide professional development in new standards in a short period of time to all teachers and the commitment to helping solve the district's problems, design and spread happened almost simultaneously. There was also attention to building an infrastructure to support mutual learning across the boundaries of research and practice through someone playing a brokering or boundary spanning role. And, the team managed to conduct "traditional" research focused both on documenting the impact of their innovations within the partnership and on developing theory (Briggs \& Furtak, 2019; Fine \& Furtak, 2020; Furtak et al., 2016).

\subsubsection{Expanding People into Multiple Projects}

As the partnership has continued, the circle of participation has grown and expanded as the university-based team has brought in new researchers. This was necessary to bring in expertise needed to support and expand access to research and professional development opportunities for teachers in the district. Brokering in additional expertise and inducting new members of partnerships is a critical aspect of adaptation within an RPP, as illustrated here and in other accounts of RPPs that have been sustained for many years (e.g., Snow \& Donovan, 2018; Penuel \& Gallagher, 2017).

\subsubsection{Infrastructuring}

Over the course of the six-years long partnership, the logic of evolution has been supported as researchers worked with the district to establish infrastructures that supported the partnership's learning. These included securing funding to hire a dedicated teacher on special assignment within the district to help broker data sharing and professional development across the district and university. In addition, the universi- 
ty-based researcher brought in additional researchers from the university with expertise in elementary and bilingual education, as well as IRT and Rasch Modeling. This kind of brokering of expertise has been an essential support for helping the RPP learn as an enterprise - that is, to grow new capacities for leading professional development (know-how) and for developing relationships with multiple stakeholders across the boundaries of research and practice (know-who).

\subsubsection{Adaptability}

In part because of these long-term relationships, the project has now persisted through multiple policy shifts and district reorganizations, and into the pandemic of 2020. While the district has officially stated that no new research can be conducted, the partnership has collaborated to build asynchronous structures for high school teachers to share their ideas and areas of need during the pandemic online, where both researchers and district curriculum coordinators can provide resources and support. Thus, an essential feature of the partnership is that the relationship does not end when an individual research project ends; instead, the committed relationships enable collaborative joint work to continue.

\subsubsection{Tensions Between Logic of Efficiency and Logic of Evolution}

As the partnership has grown, tensions between the logic of efficiency and the logic of evolution have manifested across different individual projects. For example, while the NSF grant funded the formation of a leadership structure and communication between the university and district, a second NSF grant featured a quasi-experimental study that prioritized a research design similar to that in Furtak's earlier studies with specific processes for formative assessment task design, curriculum implementation, and post-testing of students. The need for the researchers to follow this design in the context of shifting state and district priorities meant that mutual goals were not served, and researchers found themselves having discussions with district leaders around the needs of the grant, rather than growing and deepening the partnership. In these moments, the interactions felt "transactional" rather than focused on adaptation or mutual learning.

\subsubsection{Funding Challenges}

As the partnership enters its seventh year, its continuation is in part predicated on - and also threatened by - the ability of university and district partners to obtain funding to sustain the partnership. The partnership is now faced with the challenge of maintaining infrastructures with significantly decreased or potentially no exter- 
nal funding. Looking forward, the partnership must determine what activities may be maintained by existing district and university funds, essentially shrinking/retrofitting project activities into continuing sources of funding that can sustain the partnership.

\section{Possibilities and Challenges to RPPs and to Evolutionary Logics in the U.S. and Germany}

The growth of the Aspire partnership, as well as its challenges, speak to both the potential and the threats to an evolutionary logic of school improvement within the United States. The Aspire partnership is similar to many others that we have studied as a research team and documented elsewhere, in terms of its adaptability (Farrell et al., 2018). It is also similar to other RPPs we have studied in its successful reliance on boundary spanners to broker connections between researchers and educators to support mutual learning (Davidson \& Penuel, 2019). At the same time, it remains vulnerable to changes in the environment and must adapt to funding structures that are organized according to logics of efficiency rather than evolution.

The context of the United States is different from that of Germany, but the two countries share a strong tradition of federalism or local autonomy that points to the potential of place-based partnerships like Aspire that are increasingly common in the United States. Place-based partnerships are ones that are tied to local jurisdictions at the city or state level, as Aspire is. Place-based partnerships have the advantage of tuning work to fit the local policies and cultures of schools and communities and building trust through sustained opportunities for interaction between researchers and practitioners (Campano, Ghiso, Yee \& Pantoja, 2013). Already, such partnerships have begun to take on persistent problems of equity associated with limited social resources in communities (e.g., Bremm \& Racherbäumer, 2018).

At the national level, a key lever for change in Germany are the academic standards, or Bildungsstandards. In Germany, the breadth of these standards leaves considerable room for partnerships to be engaged in supporting work at the federal state level to co-create curricula (Kernlehrpläne). Curricular co-design is a particularly common and useful leading activity for partnerships, as it enables significant exchange of expertise and supports the learning of educators involved in the process while simultaneously producing materials that can directly support student learning (Pieters, Voogt \& Roblin, 2019; Voogt, Laferrière, Breuleux, Itow, Hickey \& McKenney, 2015). It is a relatively short step from co-design activities that take place within accompanying research projects (e.g., Kämäräinen, 2017) to organizing co-design within partnerships, though new tensions between teachers' and leaders' goals for change can be anticipated and must be navigated (see, e.g., Johnson, Severance, Penuel \& Leary, 2016). 
Still another potential area of focus of work for research-practice partnerships in Germany is the co-creation or co-design of resources to meet standards for teacher training (Standards für die Lehrerbildung). As experienced teachers retire, there is an opportunity to rethink long-established approaches to teacher education to better prepare teachers for classroom practice. University faculty designing courses for teacher preparation might consider working with practicing teachers and leaders in local school districts to create courses that address common puzzles of practice that teachers in the area struggle with, while also meeting standards. These partnerships might be organized as multi-tiered partnerships involving federal-state leaders as partners, to ensure coordination across the local and state level.

Both in the U.S. and Germany, RPPs can only achieve their potential if a logic of evolution is able to influence action in the wider environments of schooling. For that to occur requires new capacities and resources (e.g., funding) that will allow it to compete with the dominant logics of efficiency in each country (Peurach et al., 2019). The research-to-practice model of research and development that emphasizes development and testing in small numbers of classrooms before disseminating innovations widely is not only at odds with the needs and demands of practice, but also with the strategy RPPs use of following the contours of a problem, adding people and projects as needed to adapt to changing environments and conduct research that is both practically useful and contributes to educational research knowledge. Political pressures to find effective interventions quickly within a short grant cycle add to the pressures on RPPs, which may take more time to develop into resilient enterprises.

Ultimately, survival of RPPs in both countries will require new infrastructures. These include infrastructures for funding, which could support longer-term investments in RPPs or "tiered" investments where subsequent funding is supported if particular benchmarks of success are met. It will also require new infrastructures for developing researchers and educators to engage in this type of work. Different knowledge and skills are needed for researchers than are traditionally taught within educational psychology and education more broadly, such as partnership development and collaborative design. And institutionalized opportunities for teachers and leaders to grow through participation in research such as those provided in accompanying research are needed to complement efforts targeting researchers. From our experience as both leaders of and scholars in RPPs, building these infrastructures is not only necessary but also a rewarding form of work that makes us hopeful about the potential of research to contribute to the improvement of practice. 
William R. Penuel, Erin Marie Furtak \& Caitlin C. Farrell

\section{References}

Akkerman, S. F., \& Bakker, A. (2011). Boundary Crossing and Boundary Objects. Review of Educational Research, 81 (2), 132-169. https://doi.org/10.3102/0034654311404435

Aldrich, H. E. (1999). Organizations Evolving. London et al.: Sage.

Altrichter, H., \& Feindt, A. (2004). Handlungs- und Praxisforschung. In W. Helsper \& J. Böhme (Eds.), Handbuch der Schulforschung (pp. 449-466). Wiesbaden: VS. https://doi. org/10.1007/978-3-663-10249-6_15

Altrichter, H., \& Posch, P. (2007). Lehrerinnen und Lehrer erforschen ihren Unterricht: Unterrichtsentwicklung und Unterrichtsevaluation durch Aktionsforschung $\left(4^{\text {th }}\right.$, rev. and ext. ed.). Bad Heilbrunn: Klinkhardt.

Asen, R., Gurke, D., Solomon, R., Conners, P., \& Gumm, E. (2011). “The Research Says": Definitions and Uses of a Key Policy Term in Federal Law and Local School Board Deliberations. Argumentation and Advocacy, 47, 195-213. https://doi.org/10.1080/000 28533.2011.11821747

Blazar, D., \& Kraft, M. A. (2019). Balancing Rigor, Replication, and Relevance: A Case for Multiple-Cohort, Longitudinal Experiments. AERA Open, 5 (3), 1-18. https://doi. org/10.1177/2332858419876252

Booth, J. L., Cooper, L. A., Donovan, M. S., Huyghe, A., Koedinger, K., \& Pare-Blagoev, E. J. (2015). Design-based Research within the Constraints of Practice: AlgebraByExample. JESPAR - Journal of Education for Students Placed at Risk, 20 (1-2), 79-100. https:// doi.org/10.1080/10824669.2014.986674

Borko, H., Carlson, J., Mangram, C., Anderson, R., Fong, A., Million, S., Mozenter, S., \& Villa, A. M. (2017). The Role of Video-Based Discussion in Model for Preparing Professional Development Leaders. International Journal of STEM Education, 4 (29), 1-15. https://doi.org/10.1186/s40594-017-0090-3

Bremm, N., \& Manitius, V. (2019). Knowledge Brokerage through Research-PracticeAdministration Partnerships: Learnings from Germany. In J. Malin \& C. Brown (Eds.), The Role of Knowledge Brokers in Education: Connecting the Dots between Research and Practice (pp. 139-153). London \& New York, NY: Routledge. https://doi. org/10.4324/9780429462436-10

Bremm, N., \& Racherbäumer, K. (2018). Intersectionality and Social Space: Educational Justice in Deprived Schools. Improving Schools, 21 (1), 5-18. https://doi.org/10.1177/ 1365480217749005

Briggs, D.C., \& Furtak, E. M. (2019). Learning Progressions and Embedded Assessment. In S. M. Brookhart \& J. H. McMillan (Eds.), Classroom Assessment and Educational Measurement (pp. 1-24). London \& New York, NY: Routledge. https://doi.org/10.4324/ 9780429507533-9

Bryk, A. S., Gomez, L. M., Grunow, A., \& LeMahieu, P. G. (2015). Learning to Improve: How America's Schools Can Get Better at Getting Better. Cambridge, MA: Harvard University Press.

Callahan, R. E. (1962). Education and the Cult of Efficiency. Chicago, IL: University of Chicago Press.

Campano, G., Ghiso, M. P., Yee, M., \& Pantoja, A. (2013). Toward Community Research and Coalitional Literacy Practices for Educational Justice. Language Arts, 90 (5), 314326.

Coburn, C. E., \& Penuel, W. R. (2016). Research-Practice Partnerships in Education: Outcomes, Dynamics, and Open Questions. Educational Researcher, 45 (1), 48-54. https://doi.org/10.3102/0013189X16631750 
Cohen, D. K., \& Mehta, J. (2017). Why Reform Sometimes Succeeds: Understanding the Conditions That Produce Reforms That Last. American Educational Research Journal, 54 (4), 644-690. https://doi.org/10.3102/0002831217700078

Contandriopoulos, D., Lemire, M., Denis, J.-L., \& Tremblay, E. (2010). Knowledge Exchange Processes in Organizations and Policy Arenas: A Narrative Systematic Review of the Literature. The Milbank Quarterly, 88 (4), 444-483. https://doi.org/10.1111/j.14680009.2010.00608.x

Davidson, K. L., \& Penuel, W. R. (2019). How Brokers Negotiate Joint Work at the Boundaries. In J. Malin \& C. Brown (Eds.), The Role of Knowledge Brokers in Education: Connecting the Dots between Research and Practice (pp. 154-167). London \& New York, NY: Routledge.

Denner, J., Bean, S., Campe, S., Martinez, J., \& Torres, D. (2019). Negotiating Trust, Power, and Culture in a Research-Practice Partnership. AERA Open, 5 (2), 1-11. https://doi. org/10.1177/2332858419858635

Donovan, M. S. (2013). Generating Improvement Through Research and Development in Educational Systems. Science, 340, 317-319. https://doi.org/10.1126/science.1236180

Donovan, M. S., Snow, C. E., \& Daro, P. (2013). The SERP Approach to Problem-solving Research, Development, and Implementation. In B. J. Fishman, W. R. Penuel, A.-R. Allen \& B. H. Cheng (Eds.). Design-based Implementation Research. National Society for the Study of Education Yearbook, 112 (1), 400-425.

Dynarski, M. (2006). Advancing the Use of Scientifically Based Research in Forming Policy: A Response to Mahoney and Zigler. Applied Developmental Science, 27, 295-297. https://doi.org/10.1016/j.appdev.2006.05.002

Farrell, C. C., Davidson, K. L., Repko-Erwin, M., Penuel, W. R., Quantz, M., Wong, H., Riedy, R., \& Brink, Z. (2018). A Descriptive Study of the IES Researcher-Practitioner Partnerships in Education Research Program. Washington, DC: National Center for Research in Policy and Practice.

Farrell, C. C., Harrison, C., \& Coburn, C. E. (2019). "What the Hell Is This, Who the Hell Are You?" Role and Identity Negotiation in Research-Practice Partnerships. AERA Open, 5 (2), 1-13. https://doi.org/10.1177/2332858419849595

Farrell, C. C., Penuel, W. R., Allen, A.-R., Anderson, E. R., Bohannon, A. X., Coburn, C. E., \& Brown, S. L. (2020). Mutual Learning at the Boundaries of Research and Practice: A Framework for Understanding Research-Practice Partnerships. In M. Gresalfi \& I. S. Horn (Eds.), The Interdisciplinarity of the Learning Sciences: $14^{\text {th }}$ International Conference of the Learning Sciences, Vol. 5 (pp. 2515-2522). Nashville, TN: International Society of the Learning Sciences.

Farrell, C. C., Penuel, W. R., Coburn, C. E., Daniel, J., \& Steup, L. (2020). Research-Practice Partnerships Today: The State of the Field. Washington, DC: National Center for Research in Policy and Practice.

Fine, C., \& Furtak, E. M. (2020). A Framework for Science Classroom Assessment Task Design for Emergent Bilingual Learners. Science Education, 104 (3), 393-420. https:// doi.org/10.1002/sce. 21565

Fischman, G. E., Anderson, K. T., Tefera, A. E., \& Zuiker, S. J. (2018). If Mobilizing Educational Research Is the Answer, Who Can Afford to Ask the Question? An Analysis of Faculty Perspectives on Knowledge Mobilization for Scholarship in Education. AERA Open, 4 (1), 1-17. https://doi.org/10.1177/2332858417750133

Furtak, E. M. (2012). Linking a Learning Progression for Natural Selection to Teachers' Enactment of Formative Assessment. Journal of Research in Science Teaching, 49 (9), 1181-1210. https://doi.org/10.1002/tea.21054

Furtak, E. M., Circi, R. K., \& Heredia, S. C. (2018). Exploring Alignment among Learning Progressions, Teacher-designed Formative Assessment Tasks, and Student Growth: 
Results of a Four-Year Study. Applied Measurement in Education, 31 (2), 143-156. https://doi.org/10.1080/08957347.2017.1408624

Furtak, E. M., Henson, K., \& Buell, J. (2016, April). Negotiating Goals around Formative Assessment in a Research-Practice Partnership. NARST International Conference, Baltimore, MD.

Furtak, E. M., Ruiz-Primo, M. A., Shemwell, J. T., Ayala, C. C., Brandon, P. R., Shavelson, R. J., \& Yin, Y. (2008). On the Fidelity of Implementing Embedded Formative Assessment and Its Relation to Student Learning. Applied Measurement in Education, 21, 360-389. https://doi.org/10.1080/08957340802347852

Furtak, E. M., Thompson, J., Braaten, M., \& Windschitl, M. (2012). Learning Progressions to Support Ambitious Teaching Practices. In A. C. Alonzo \& A. W. Gotwals (Eds.), Learning Progressions in Science: Current Challenges and Future Directions (pp. 405434). Rotterdam: Sense Publishers. https://doi.org/10.1007/978-94-6091-824-7_17

Hannan, M. T., \& Freeman, J. H. (1989). Organizational Ecology. Cambridge, MA: Harvard University Press.

Haskins, R., \& Baron, J. (2011). Building the Connection between Policy and Evidence: The Obama Evidence-based Initiatives. Date of access: 12.01.2021. Retrieved from https:// www.brookings.edu/research/building-the-connection-between-policy-and-evidencethe-obama-evidence-based-initiatives/.

Henrick, E. C., Cobb, P., Penuel, W. R., Jackson, K., \& Clark, T. R. (2017). Assessing Research-Practice Partnerships: Five Dimensions of Effectiveness. New York, NY: William T. Grant Foundation.

Huguet, A., Allen, A.-R., Coburn, C. E., \& Farrell, C. C. (in press). Constraints, Values, and Information: How District Leaders Justify Their Positions during Instructional Deliberation. American Educational Research Journal.

Johnson, R., Severance, S., Penuel, W. R., \& Leary, H. A. (2016). Teachers, Tasks, and Tensions: Lessons from a Research-Practice Partnership. Journal of Mathematics Teacher Education, 19 (2), 169-185. https://doi.org/10.1007/s10857-015-9338-3

Jonçich, G. M. (1968). The Sane Positivist: A Biography of Edward L. Thorndike. Middletown, CT: Wesleyan University Press.

Kämäräinen, P. (2017, August). Begleitforschung as Mediator between Action-oriented Learning and Digital Change: On the Role of Accompanying Research and Training Interventions in the Learning Layers Construction Pilot. European Educational Research Association Conference, Copenhagen, Denmark.

Koninklijke Nederlandse Akademie van Wetenschappen. (2018). Maatschappelijke impact in kaart [Mapping Social Impact]. Author.

Lagemann, E. C. (1997). Contested Terrain: A History of Education Research in the United States, 1890-1990. Educational Researcher, 26 (9), 5-17. https://doi.org/10.3102/ 0013189X026009005

Lagemann, E. C. (2002). An Elusive Science: The Troubling History of Education Research. Chicago, IL: University of Chicago Press.

Mehta, J. (2013). How Paradigms Create Politics: The Transformation of American Educational Policy, 1980-2001. American Educational Research Journal, 50 (2), 285324. https://doi.org/10.3102/0002831212471417

NGSS Lead States. (2013). Next Generation Science Standards: For States, by States. Washington, DC: National Academies Press.

Oakes, J., \& Rogers, J. (2007). Radical Change through Radical Means: Learning Power. Journal of Educational Change, 8 (3), 193-206.

Penuel, W. R. (2019). Infrastructuring as a Practice of Design-based Research for Supporting and Studying Equitable Implementation and Sustainability of Innovations. Journal of the Learning Sciences, 28 (4-5), 659-677. https://doi.org/10508406.2018.1552151 
Penuel, W. R., Allen, A.-R., Farrell, C., \& Coburn, C. E. (2015). Conceptualizing ResearchPractice Partnerships as Joint Work at Boundaries. JESPAR - Journal for Education of Students Placed at Risk, 20 (1-2), 182-197. https://doi.org/10.1080/10824669.2014.988 334

Penuel, W. R., Coburn, C. E., \& Gallagher, D. (2013). Negotiating Problems of Practice in Research-Practice Partnerships Focused on Design. In B. J. Fishman, W. R. Penuel, A.-R. Allen \& B. H. Cheng (Eds.), Design-based Implementation Research: Theories, Methods, and Exemplars (National Society for the Study of Education Yearbook) (pp. 237-255). New York, NY, et al.: Teachers College Record.

Penuel, W. R., DeBarger, A. H., Boscardin, C. K., Moorthy, S., Beauvineau, Y., Kennedy, C., \& Allison, K. (2017). Investigating Science Curriculum Adaptation as a Strategy to Improve Teaching and Learning. Science Education, 101 (1), 66-98. https://doi. org/10.1002/sce.21249

Penuel, W. R., \& Gallagher, D. (2017). Creating Research-Practice Partnerships in Education. Cambridge, MA: Harvard Education Press.

Penuel, W. R., Riedy, R., Barber, M., Peurach, D. J., LeBoeuf, W., \& Clark, T. L. (2020). Principles of Collaborative Education Research with Stakeholders: Toward Requirements for a New Research and Development Infrastructure. Review of Educational Research. https://doi.org/10.3102/0034654320938126

Peurach, D. J., \& Glazer, J. L. (2012). Reconsidering Replication: New Perspectives on Largescale School Improvement. Journal of Educational Change, 13 (2), 155-190. https://doi. org/10.1007/s10833-011-9177-7

Peurach, D. J., Penuel, W. R., \& Russell, J. L. (2019). Beyond Ritualized Rationality: Organizational Dynamics of Instructionally-focused Continuous Improvement. In M. Connolly, D. H. Eddy Spicer, C. James, \& S. D. Kruse (Eds.), SAGE International Handbook of School Organization (pp. 465-488). London et al.: Sage. https://doi. org/10.4135/9781526465542.n28

Pieters, J. M., Voogt, J. M., \& Roblin, N. N. P. (Eds.). (2019). Collaborative Curriculum Design for Sustainable Innovation and Teacher Learning. Cham: Springer International Publishing. https://doi.org/10.1007/978-3-030-20062-6

Roderick, M., Easton, J. Q., \& Sebring, P. B. (2009). The Consortium on Chicago School Research: A New Model for the Role of Research in Supporting Urban School Reform. Chicago, IL: Consortium on Chicago School Research.

Russell, J. L., Bryk, A. S., Dolle, J. R., Gomez, L. M., LeMahieu, P. G., \& Grunow, A. (2017). A Framework for the Initiation of Networked Improvement Communities. Teachers College Record, 119, 1-36.

Russell, J. L., Correnti, R. J., Stein, M. K., Bill, V., Hannan, M., Schwartz, N. L., Booker, L. N., \& Pratt, N. R. (2020). Learning from Adaptation to Support Instructional Improvement at Scale: Understanding Coach Adaptation in the TN Mathematics Coaching Project. American Educational Research Journal, 57 (1), 148-187. https://doi. org/10.3102/0002831219854050

Scott, J., Lubienski, C., DeBray, E., \& Jabbar, H. (2014). The Intermediary Function in Evidence Production, Promotion, and Utilization: The Case of Educational Incentives. In K. S. Finnigan \& A. J. Daly (Eds.), Using Research Evidence in Education: From the Schoolhouse Door to Capitol Hill (pp. 69-92). Cham: Springer International Publishing. https://doi.org/10.1007/978-3-319-04690-7_6

Snow, C. E., \& Donovan, M. S. (2018). Sustaining Research-Practice Partnerships: Benefits and Challenges of a Long-term Research and Development Agenda. In B. Bevan \& W. R. Penuel (Eds.), Connecting Research and Practice: New Models for Equity and Ethics (pp. 33-50). London \& New York, NY: Routledge. https://doi.org/ 10.4324/9781315268309-3 
Spillane, J. P., \& Burch, P. (2006). The Institutional Environment and Instructional Practice: Changing Patterns of Guidance and Control in Public Education. In H.-D. Meyer \& B. Rowan (Eds.), The New Institutionalism in Education (pp. 87-102). New York, NY: State University of New York Press.

Voogt, J. M., Laferrière, T., Breuleux, A., Itow, R. C., Hickey, D. T., \& McKenney, S. E. (2015). Collaborative Design as a Form of Professional Development. Instructional Science, 43 (2), 259-282. https://doi.org/10.1007/s11251-014-9340-7

William R. Penuel, Ph. D., Distinguished Professor of Learning Sciences and Human Development in the Institute of Cognitive Science and School of Education at the University of Colorado Boulder.

E-Mail: william.penuel@colorado.edu

Caitlin Farrell, Ph. D., Associate Research Professor in the School of Education at the University of Colorado Boulder and Director of the National Center for Research in Policy and Practice.

E-Mail: caitlin.farrell@colorado.edu

Erin Marie Furtak, Ph.D., Professor of STEM Education and Associate Dean of Faculty at the School of Education, University of Colorado Boulder.

E-Mail: erin.furtak@colorado.edu

Address: Institute of Cognitive Science and School of Education, University of Colorado Boulder, 1777 Exposition Drive, Boulder, CO 80301, U.S.A. 